\title{
Potential Antibacterial Activity of Hibiscus rosasinensis Linn Flowers Extracts
}

\author{
Eman A. Sobhy ${ }^{1}$, Khadiga G. Abd Elaleem ${ }^{1,2 *}$ and Hagir G. Abd Elaleem ${ }^{3}$ \\ ${ }^{1}$ Department of Biology, Faculty of Science and Art, Alkhafji HafrElbatin University, \\ Saudi Arabia \\ ${ }^{2}$ Department of Biology and Biotechnology, AL Neelain University / Faculty of Science \\ and Technology, Khartoum/ Sudan \\ ${ }^{3}$ Department of Physics, Faculty of Art and Science, Al-Aardha, JazanUneversity, \\ Box.114, Jazan, Saudi Arabia \\ *Corresponding author:
}

\section{A B S T R A C T}

\section{Keywords}

Hibiscus rosasinensis, Pathogenic bacteria extracts, Sensitivity test Pseudomonas aeruginosa, Staphylococcus aureus Escherichia coli, Antibiotics.

\section{Article Info}

Accepted:

12 March 2017

Available Online:

10 April 2017
Hibiscus rosasinensis is member of the family Malvaceae, grow as green herbaceous plant in tropical regions. It is a tropical shrub, with large, glossy green leaves and spectacular trumpet shaped flowers. Its medicinal values have been mentioned in traditional folk medicines for variety of diseases. The objective of this study is to determine the phytochemical constituent using different solvent and to study the antibacterial effect of methanol extract at different concentration against three bacteria. Phytochemical screening of $H$. rosasinensis flower by four extraction solvents are carried out and antibacterial activity of three concentration of methanol extracts were screened against some bacteria such as Escherichia coli, Pseudomonas aeruginosa and Staphylococcus aureus. Methanol extract of hibiscus exhibits highest extraction yield value, followed by Ethanol, water and Ethyl acetate respectively. The phytochemical screening exhibited the presence of different component like Alkaloids, Glycosides, Carbohydrates, Phytosterols, Phenolic compound, Tannins, Saponins, Flavonoids, Proteins and Aminoacids. Methanol extracts at high concentration were exhibited maximum antibacterial potentiality of $H$. rosasinensis flower against Escherichia coli, Pseudomonas aeruginosa and Staphylococcus aureus respectively. The phytochemical analysis of Hibiscus rosasinensis flower extracts reported the present of different medicinal valuable constituents includes Alkaloids, Glycosides, Carbohydrates, Phytosterols, Phenolic compound, Tannins, Saponins, Flavonoids, and Proteins and Aminoacids. Our findings prove that, the flower of $\mathrm{H}$. rosa-sinensis plants have medicinal antibacterial activities and can use against bacteria under study. Methanol extract obtained highest yield and antibacterial activity at high concentration, so it could be subjected to isolate different active medicinal valuable compound of $H$. rosasinensis $\mathrm{L}$. The present findings suggest that methanol is a good solvent for extracting antibacterial agents. Further studies are needed to investigate individual phytochemical compound of the flower of Hibiscus rosasinensis. The flower extract of $H$. rosasinensis $L$. can be considered to be as equally potent as the most of effective artificial antibiotics. 


\section{Introduction}

Plants contain secondary metabolites, which are organic compounds that are not directly involved in the normal growth, development, or reproductions of organisms but often play an important role in plant defenses (Harbone and Baxter, 1993). Examples include alkaloids, glycosides, terpenoids, phenols, tannins, flavonoids and saponins (Edema and Alaga, 2012). Furthermore, there is growing interest in the chemical composition of plants towards discovery of more effective biotherapeutic agents (Roja and Rao, 2002). The importance of natural products in modern medicine has been discussed in recent reviews and research (Newman et al., 2003; Koehn and Carter, 2005 and Jones et al., 2006).

Hibiscus rosasinensis, a highly potential functional and valuable medicinal plant, has been reported in the ancient medicinal literature with beneficial effects in various disorders of humans. This is a tropical shrub, with large, glossy green leaves and spectacular trumpet shaped flowers. Its medicinal values have been mentioned in traditional folk medicines for variety of diseases. Recent studies shown that Hibiscus rosasinensis extract from different part of plant has significant protective effects (Shivananda et al., 2007; Ruban and Gajalakshmi, 2012; Salem et al., 2013; Kannathasan et al., 2011 and Mohamed et al., 2014), thus these plants have great medicinal potential for the therapy of infection. Flowers and leaves are found to possess antioxidant, antifungal, anti-infectious, antimicrobial, antiinflammatory, anti-diarrheic and antipyretic activity (David and Leonard, 1998).

Recent studies about the phytochemical constituent and antibacterial activity of methanolic extract of leaf and flower, prove the antibacterial potential of $H$. rosa-sinensis extracts (Udin et al., 2015). Many chemical constituents have been isolated from this plant
(Tiwari et al., 2015; Al-Alak., 2015; and Khan et al., 2014). Traditionally the flower can be use as antiasthmatic agent (Zhoa et al., 2010).

\section{Methodology}

\section{Plant material and extract preparation}

Hibiscus rosa-sinensisis flower used in this study were dried in shade, and subsequently powdered. Then about $50 \mathrm{~g}$ of flower powder were subjected for extraction using different solvents ethyl acetate, ethanol, methanol and water by shaking the mixture for about one hr in a shaker at room temperature. Subsequently, samples were filtered on whatman filter paper. Then the filtrate was taken for extraction and concentration in soxhlet apparatus, by soxhlet extraction. Final extract was collected in sterile labeled containers. Then different extractions kept in refrigerator at $4{ }^{\circ} \mathrm{C}$ for screening their phytochemichal constituent and detect antibacterial activity.

\section{Phytochemical screening}

Phytochemical screening of flower extract was tested for the presence of phytochemical constitutes by standard procedures followed by (Debela, 2002).

\section{Antibacterial activity}

Antibacterial activity was carried out as per British pharmacopeia using three concentration of flower methanol extract, (25 $\mathrm{mg}, 50 \mathrm{mg}$ and $100 \mathrm{mg}$ ) of methanol extract was weighed and dissolved in $100 \mathrm{ml}$ of methanol.

\section{Standard}

Discs impregnated in chloramphenicol were used as standard (CT0012B, C10 $\mu \mathrm{g}$ Oxoid 
Limited, Wade Road, Basingstoke, Hampshire, RG24 8PW, England).

$10 \mu \mathrm{g}$ of chroramphenicol has used as a standard antibiotic its shows zone of inhibition around $24 \mathrm{~mm}$.

\section{Results and Discussion}

Data in table 1 obtained that, methanol extract of hibiscus exhibits highest extraction yield value $(29.75 \mathrm{~g})$, followed by Ethanol, water and Ethyl acetate as $(22.95,22.25$ and 20.90 g) respectively Furthermore, methanol has stronger extraction capacity which could be helpful in extracting greater number of active constituents responsible for antibacterial activity, this result in agreement with (Tiwari et al., 2015; Khan et al., 2014 and Abdelaleem et al., 2016).

Data in table 2 represent the phytochemical analysisof Hibiscus rosasinens flower, the methanol extract of Hibiscus rosasinens flower contained varied type of phytochemical compound include Alkaloids, Glycosides, Carbohydrates, Phytosterols, Phenolic compound, Tannins, Saponins, Flavonoids, and Proteins and Aminoacids, and Alkaloids, Glycosides, Carbohydrates, Phytosterols, Phenolic compound, Tannins, and Flavonoids, in water extract, Alkaloids, Glycosides, Carbohydrates, Phytosterols, Phenolic compound, and Tannins in ethanol extract, Alkaloids, Glycosides, Carbohydrates, Phytosterols and Flavonoid in Ethyl acetate extract, this finding in agreement with (Tiwari et al., 2015) study the phytochemical constituent and antibacterial potential of flower and leaf methanolic extract of $H$. rosasinensis and reported that, the phytochemical analysis showed present of alkaloid, glycoside, flavonoid, tannin and phenol in $H$. rosasinensis leaf extract, and alkaloid, protein, steroid, and carbohydrate in $H$. rosasinensis flower extract.
Antibacterial activity of methanol extracts prepared from flowers of $H$. rosasinensis L., were screened against some bacteria such as Escherichia coli, Streptococcus pyogenes and Staphylococcus aureus (Table 3). All flower methanol extracts at high concentration exhibited antibacterial potentiality of $H$. Rosasinensis.

In the present investigation flower methanol extract screened for antibacterial activity against Escherichia coli, Pseudomonas aeruginosa and Staphylococcus aureus. Antibacterial activity has been obtained in term of inhibition zone by cup- plate method, using three concentration of methanol flower extract as shown in table 3. All bacteria represent increasing in inhibition zone diameter with increasing of methanol extract concentration. Among all treatment, highest zone inhibition observed from flower methanol extract at concentration $1 \mathrm{mg} / \mathrm{ml}$, for E. coli $(27 \pm 0.12) \mathrm{mm}$, this finding agree with Al-Alak et al., 2015; Ruban and Gajalakshmi, 2012 and Kumar et al., 2010), followed by Staphylococcus aureus with $(21 \pm 0.41) \mathrm{mm}$ inhibition zone at the same flower extract concentration (Figure 1 and 2). Methanol extract at high concentration $(1 \mathrm{mg} / \mathrm{ml})$ showed maximum inhibition zone against $E$. coli, Staphylococcus aureus and Streptococcus pyogenes as $(27 \pm 0.12,21 \pm 0.41$, and $18 \pm 0.65) \mathrm{mm}$, followed by $0.5 \mathrm{mg} / \mathrm{ml}$ methanol extract showed maximum inhibition zone against $E$. coli as $(17 \pm 0.21) \mathrm{mm}$, this finding in agree with the finding of (Uddin $e t$ al., 2010), reported that the methanolic extract of hibiscus flower obtain antibacterial effect at high concentration.

The bio active substances in plants are produced as secondary metabolite. Whiles plant leave, stem, root and bark have been widely evaluated for medicinal value, phytochmical screening of different plant flower has not been studied extensively. 
The phytochemical analysis of flower of Hibiscus rosasinensis extracts reported the present of different medicinal valuable constituents includes Alkaloids, Glycosides, Carbohydrates, Phytosterols, Phenolic compound, Tannins, Saponins, Flavonoids, and Proteins and Aminoacids. From the preliminary screening, it has been obtained that methanol extract of hibiscus exhibits highest yield value,

Table.1 Extraction yield of Hibiscus rosasinensis flower

\begin{tabular}{|c|l|c|}
\hline S. No. & Solvent & Yield $(\mathbf{g})$ / 100 g flower powder \\
\hline 1. & Ethyl acetate & 20.90 \\
\hline 2. & Methanol & 29.75 \\
\hline 3. & Ethanol & 22.95 \\
\hline 4. & Water & 22.25 \\
\hline
\end{tabular}

Table.2 Phytochemical analysisof Hibiscus rosasinensis flower

\begin{tabular}{|l|c|c|c|c|}
\hline Test for & $\begin{array}{l}\text { Ethyl acetate } \\
\text { extract }\end{array}$ & $\begin{array}{l}\text { Methano } \\
\text { lextract }\end{array}$ & $\begin{array}{l}\text { Ethanol } \\
\text { extract }\end{array}$ & Water extract \\
\hline Alkaloids & ++ & +++ & ++ & ++ \\
\hline Glycosides & + & +++ & + & + \\
\hline Carbohydrates & + & +++ & ++ & + \\
\hline Phytosterols & ++ & +++ & ++ & ++ \\
\hline Phenolic compound & - & +++ & ++ & ++ \\
\hline Tannins & - & +++ & ++ & ++ \\
\hline Saponins & - & + & - & - \\
\hline Flavonoids & ++ & +++ & - & ++ \\
\hline ProteinsandAminoacids & - & ++ & - & - \\
\hline
\end{tabular}

+ present, - Absent, ++ moderate, +++ abundant

Table.3 Antibacterial activity of methanol extracts of Hibiscus rosasinensis L. flowers against some bacteria

\begin{tabular}{|c|l|l|l|l|}
\hline Serial No & organism & \multicolumn{3}{|c|}{ Inhibition zone $(\mathrm{mm})$} \\
\cline { 3 - 5 } & & $0.25 \mathrm{mg} / \mathrm{ml}$ & $0.5 \mathrm{mg} / \mathrm{ml}$ & $1 \mathrm{mg} / \mathrm{ml}$ \\
\hline 1 & E.coli & $13 \pm 0.25$ & $17 \pm 0.21$ & $27 \pm 0.12$ \\
\hline 2 & $\begin{array}{l}\text { Staphylococcus } \\
\text { aureus }\end{array}$ & $10 \pm 0.45$ & $15 \pm 0.11$ & $21 \pm 0.41$ \\
\hline 3 & $\begin{array}{l}\text { Streptococcus } \\
\text { pyogenes }\end{array}$ & $8 \pm 0.31$ & $9 \pm 0.10$ & $18 \pm 0.65$ \\
\hline
\end{tabular}

* $10 \mu \mathrm{g}$ of Chroramphenicol has used as a standard antibiotic its shows zone of inhibition around $24 \mathrm{~mm}$.

*More than $15 \mathrm{~mm}$ of zone of inhibition consider as moderate antimicrobial activity. 


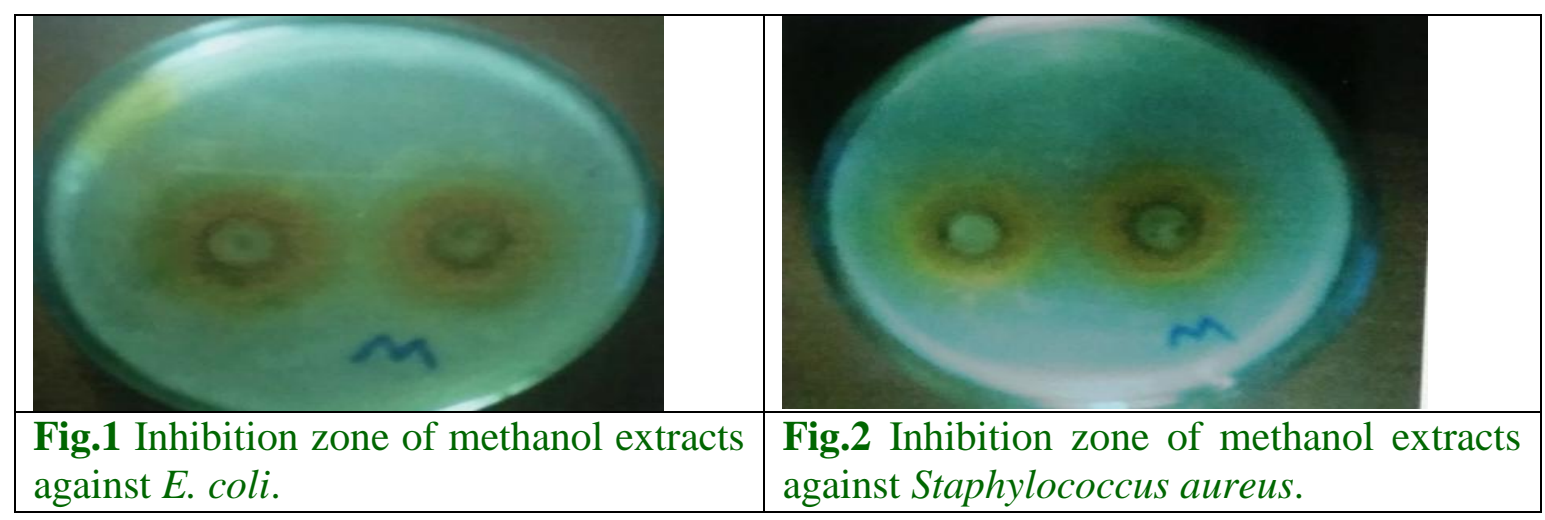

Furthermore, methanol has stronger extraction capacity which could be helpful in extracting greater number of active constituents responsible for antibacterial activity, these results in agreement with (Tiwari et al., 2015), reported that, the phytochemical analysis showed present of alkaloid, glycoside, flavonoid, tannin and phenol in $H$. rosasinensis leaf extract, and alkaloid, protein, steroid, and carbohydrate in Hibiscus rosasinensis flower extract. The antibacterial activity of plant extracts depends on the available bioactive secondary metabolites in the plant part. There are several published report on bacterial activity of different part extract of Hibiscus rosasinensis (Krishnaiah, et al., 2009, Anyasor et al., 2010; Kumar et al., 2010; Tiwari et al., 2015 and Al-Alak et al., 2015).

In conclusion, the phytochemical analysis of the medicinal plants are important and have commercial interest in both research Centre and pharmaceuticals companies for the manufacturing of the new drugs for treatment of various diseases. Further detailed studies on isolation of phytoconstituents of the plant extracts are essential to characterize them as biological antimicrobial. Medicinal plants have a promising future because there are about half million plants around the world, and most of them their medical activities have not investigate yet, and their medical activities could be decisive in the treatment of vital disease. The phytochemical analysis of Hibiscus rosasinensis flower extracts reported the present of different medicinal valuable constituents includes alkaloids, glycosides, carbohydrates, phytosterols, phenolic compound, tannins, saponins, flavonoids, and proteins and amino acids. Methanol has stronger extraction capacity which could be helpful in extracting greater number of active constituents responsible for antibacterial activity, our findings prove that, the flower of $H$. rosasinensis plants have medicinal antibacterial activities and can use against bacteria under study. The findings of this study support the view, that the methanol extract of Hibiscus rosasinensis flower are promising sources of potential antibacterial value and may be efficient as preventive agents for some diseases. Methanol extract obtained highest yield and antibacterial activity at high concentration, so it could be subjected to isolate different active medicinal valuable compound. The present findings suggest that methanol is a good solvent for extracting antibacterial agents. In conclusion, the results obtained in this study, clearly demonstrate varied antibacterial activity of Hibiscus rosasinensis flower extracts more importantly the results indicated that the presence of phyto compounds including phenols, tannins and flavonoids constituents may be responsible for these Antibacterial activities. Further studies are needed to investigate individual phytochemical 
compound of the flower of Hibiscus rosasinensis and identification and structural determination of novel antimicrobial compounds will lead to the development of therapeutics from these plants.

\section{References}

Abd Elaleem, G.H., Alsheikh A. Albasheer, A.A., and Khadiga G. AbdElaleem, G. Kh. 2016. Phytochemical Screening And Antibacterial Activity Of Punica granatum Fruit Rind Extracts. Global J. Med. Plant Res., 4(4): 9-15.

Al-Alak, Kh.Sh., R.M.S. AL-Oqaili., Mohammed, B. B., and Abd-Alkhalik, N. 2015. Antibacterial Activity of Hibiscus rosasinensis Extract and Synergistic Effect with Amoxicillin against some Human Pathogens. American J. Phytomed. Clin. Therapeutics, 3(01): 020-027.

Anyasor, G.N., Ogunwenmo, K.O., Oyelana, O.A., Akpofunure, B.E., 2010. Phytochemical constituents and antioxidant activities of aqueous and methanol stem extracts of Costus afer Ker Gawl. (Costaceae). African J. Biotechnol., 9(31): 4880-4884.

David, B and L.A, Leonard. 1998. Healing plants of the Hawaiian kingdomHibiscus rosasinensis (Aloalo), Roast Duck Production.

Debela, A. 2002. Manual for Phytochemical Screening of Medicinal Plants. Ethiopian Health and Nutrition Research Institute, Addis Ababa, Ethiopia, 35-47.

Edema, M.O. and T.O, Alaga. 2012. Comparative evaluation of bioactive compounds in Hibiscus sabdariffa and Syzygium samarangense juice extracts. African Crop Sci. J., 20: 179 - 187.

Harbone, J.M and H, Baxter. 1993. Phytochemical Dictionary: A handbook of bioactive compounds from plants. Taylor and Francis Ltd. London.
Washington DC, USA, pp 755.

Jones, A.M., J. Chory., J.L. Dangl., M. Estelle., S.E. Jacobsen., E.M Meyerowitz., M. Nordborg and D. Weigel. 2008. The impact of Arabidopsis on human health research: "diversifying our portfolio", Cell, 133 . 939-943.

Kannathasan, K., A. Senthilkumar and V. Venkatesalu. 2011. In vitro antibacterial potential of some Vitex species against human pathogenic bacteria. Asian Pacific J. Trop. Med., 4: 645-648.

Khan, Z.A., S.A.R. Naqvi., Ammara Mukhtar, A., Hussain, Z., Shahzad, A.S., Mansha, A., Ahmad, M., Zahoor, F.A., Bukhari, H.I., M. R. S. A. Janjua., Mahmood, N., and Yar, M. 2014. Antioxidant and antibacterial activities of Hibiscus rosasinensis Linn flower extracts. Pak. J. Pharma. Sci., 27(3): 469-474.

Koehn, F.E. and G.T. Carter. 2005. 'The evolving role of natural products in drug discovery'. Nature Reviews Drug Discovery, 4: 206-220.

Krishnaiah, D., Devi. T., Bono. A., and Sarbatly, R. 2009. Studies on phytochemical constituents of six Malaysian medicinal plants. J. Med. Plants Res., 3: 67-72.

Kumar, S., Narian, S. 2010. Herbal remedies of wet lands macrophytes in India. Int J. Pharmacy and Biol. Sci., 1(2): 1-12.

Mohamed, Z.M., J, Salem., Olivares-Pérez and A.Z.M. Salem., 2014. Studies on biological activities and phytochemicals composition of Hibiscus species- A review. Life Sci. J., 11(5): 1-8.

Newman, D.J., G.M, Cragg and K.M. Snader. 2003. 'Natural products as sources of new drugs over the period 1981-2002'. J. Natural Products, 66: 1022-1037.

Newman, D.J., G.M. Cragg and K.M. Snader. 2000. 'The influence of natural products upon drug discovery. Natural product reports, 17: 215-234. 
Newman, D.J. and G.M. Cragg. 2010. Natural products as sources of new drugs over the 30 years from 1981 to $2010 . J$. Natural Products, 75(3): 311-35.

Ruban, P. and Gajalakshmi, K. 2012. Invitro antibacterial activity of Hibiscus rosasinensis flower extract against human pathogen. Asian Pacific J. Trop. Biomed., 2(5): 399-403.

Salem, M., Y.M. Gohar., L.M. Camacho, N.A. El-Shanhorey and M. Salem. 2013. Antioxidant and antibacterial activities of leaves and branches extracts of Tecoma stans (L.) Juss. ex Kunth against nine species of pathogenic bacteria. African $J$. Microbiol. Res., 7(5): 418-426.

Shivananda, N.B., R.S. Sivachandra., F.A. Orette and Chalapathi. 2007. Effects of Hibiscus rosasinensis L (Malvaceae) on wound healing activity: a preclinical study in a Sprague Dawley rat. Int. J. Lower Extremity Wounds, (6):76-81.

Tiwari, U., Yadav, P., and Nigam, D. 2015.
Study on Phytochemical Screening and Antibacterial Potential of Methanolic Flower and Leaf Extracts of Hibiscus rosa sinensis. Int. J. Innovative and Appl. Res., 3(6): 9- 14.

Uddin, B., Hossan, T., Paul, S., Ahmed, T., Nahar, T., Ahmed, S. 2010. Antibacterial activity of the ethanol extracts of Hibiscus rosasinensis leaves and flowers against clinical isolates of bacteria. Bangladesh J. Life Sci., 22: 6573.

Wong, S.K., Y.Y. Lim and E.W.C. Chan. 2010. Evaluation of antioxidant, anti tyrosinase and antibacterial activities of selected Hibiscus species. Ethnobotanical Leaflets, 14: 781-796.

Zhao, J., Zhou, L., Wang, J., Shan, T., Zhong, L., and Lix, X. 2010. Endophytic fungi for producing bioactive compounds originally from their host plant. Curr. Res. Technol. Education Topics in Appl. Microbiol. Microbial Biotechnol., 1: 5.

\section{How to cite this article:}

Eman. A. Sobhy, Khadiga G. Abd Elaleem and Hagir G. Abd Elaleem. 2017. Potential Antibacterial Activity of Hibiscus rosasinensis Linn Flowers Extracts. Int.J.Curr.Microbiol.App.Sci. 6(4): 1066-1072. doi: https://doi.org/10.20546/ijcmas.2017.604.132 